\title{
CONFLICT OF LAWS IN THE FEDERAL COURTS: THE ERIE ERA *
}

\section{By Paul A. Wolkin $\dagger$}

For almost a hundred years following Swift $v$. Tyson ${ }^{1}$ the Federal courts, in suits founded on diversity of citizenship, held themselves free to exercise an independent judgment in matters of "general" jurisprudence, where their only concern was the unwritten law of the state. Erie R. R. v. Tompkins ${ }^{2}$ abridged this freedom: "Except in matters governed by the Federal Constitution or by Acts of Congress, the law to be applied in any case is the law of the State. And whether the law of the State shall be declared by its Legislature in a statute or by its highest court in a decision is not a matter of federal concern. There is no federal general common law." 3

The decision in the Erie case was the culmination of a persistent and continually rising tide of criticism of the doctrine of Swift $v$. Tyson. ${ }^{4}$ The Rules of Decision Act, ${ }^{5}$ it had been indicated, was intended to apply to the decisional as well as the statutory law of a state, contrary to the construction placed upon the statute by Justice Story. ${ }^{6}$ Sreift v. Tyson had not, in the Court's opinion, achieved the benefits that had been anticipated. State courts followed their own bent, as they were entitled to do, on questions of common law and the national uniformity sought by Justice Story remained a pious hope. The outcome of a lawsuit more than ever came to depend upon the forum chosen, and the federal forum which was to protect the non-citizen from local discrimination was used by the non-citizen to deny to the citizen the benefit of the laws of his state. Finally, a majority of the court stated that if the construction in Swift $v$. Tyson of the Rules of Decision Act were valid, the statute was unconstitutional. ${ }^{7}$

* This article was prepared for the Practising Law Institute.

$\dagger$ A.B., I937, M. A., I938, LL. B., I941, University of Pennsylvania; member of the Pennsylvania Bar; Assistant General Counsel, French Supply Council.

I. I6 Pet. I (U. S. 1842).

2. 304 U. S. 64 (1938).

3. $I d$. at 78 .

4. See reference cited in notes 3 to 6 of Mr. Justice Brandeis' opinion, $304 \mathrm{U}$. S. at 72,73 .

5. 28 U. S. C. (1940 ed.) $\$ 725$.

6. Warren, New Light on the History of the Federal Judiciary Act of 1789 (1923) 37 HARV. L. REV. 49, 5I-52, 8r-88.

7. A few of the multitude of comments evoked by the Erie decision: Bowman, The Unconstitutionality of the Rule of Swift $v$. Tyson (1938) I8 B. U. L. REv. 659; Cole, 
Under Erie R. R. v. Tompkins, if A is sued in the federal court for negligent injury or breach of contract, his liability is to be determined by reference to state tort or contract law. If, for example, the tort or breach of contract occurs in Pennsylvania and suit is brought in a federal district court of that state, then the Pennsylvania law of torts or contracts is applicable. Thus, in diversity of citizenship suits since the Erie decision, the Supreme Court has required the federal courts to apply state law to determine the construction of contracts of insurance, ${ }^{8}$ the duty of a lessor of a truck to maintain it in a reasonably safe condition, ${ }^{9}$ the applicability of a liquidated damages clause in a construction contract, ${ }^{10}$ the validity of a testamentary trust, ${ }^{11}$ the liability of an employer for occupational diseases due to his negligence, ${ }^{12}$ and liability for unfair competition and common law "trademark infringement." 13

However, if a citizen of Massachusetts ran over a citizen of New York in the latter state and suit was brought in a district court of Pennsylvania, was the federal court free to determine for itself the rule of reference to the state law which it must follow? And was the same court free to determine who had the burden of proof on the issue of contributory negligence; and what evidence was sufficient to send the case to the jury or to require a directed verdict against the plaintiff? Or if the suit involved a contract where the offer had been made in Pennsylvania, accepted in New York, and which required performance in New Jersey, and equitable relief rather than a remedy at law was sought, was the doctrine of the Tompkins case still applicable? And was a federal court required to deny recovery if recovery could not be had in the state in which the federal court was sitting because it was against state public policy? Finally, was the state law which a federal judge must follow only that pronounced by the highest court of the state or were decisions of inferior tribunals also of binding effect?

Erie v. Tompkins and the Relationship Between Federal and State Courts (1942) 36 AMr. Por. ScI. REv. 885; Jackson, The Rise and Falls of Swift v. Tyson (1938) 24 A. B. A. J. 609; McCormick and Hewins, The Collapse of "General" Laze in the Federal Courts (I938) 33 ILL. L. REv. I26; Shulman, The Demise of Swift v. Tyson (I938) 47 YAIE L. J. 1336; Stimson, Swift v. Tyson-What Remains? What is (State) Law? (I938) 24 CORN. L. Q. 54.

8. Ruhlin'v. New York Life Ins. Co., 304 U. S. 202 (I938) ; New York Life Ins. Co. v. Jackson, 304 U. S. 261 (I938); Rosenthal v. New York Life Ins. Co., 304 U. S. 263 (r938).

9. Hudson v. Moonier, 304 U. S. 397 (I938).

Io. Six Companies of California v. Joint Highway District No. I3 of California, 3II, U. S. I80 (1940).

II. Fidelity Union Trust Co. v. Field, 3II U. S. I69 (1940).

I2. Vandenbark v. Owens-Illinois Glass Co., 3 II U. S. 538 (I94I).

I3. Pecheur Lozenge Co., Inc. v. National Candy Co., Inc., 3I5 U. S. 666 (I942). 
"Because of the importance of the question whether the federal court was free to disregard the alleged rule of the Pennsylvania common law, we granted certiorari." 14

In Erie R. R. v. Tompkins suit had been brought in a federal district court of New York for an alleged tort in Pennsylvania. In its opinion, the Supreme Court apparently indicated that the tort law of Pennsylvania was to be applied. It was not explained, however, whether this result followed because the federal court was free to choose its own conflict of laws rule or because the federal court must apply the conflict of laws rule of New York.

Under Swift $v$. Tyson the former probably was true: federal courts were free to exercise their independent judgment in arriving at the conflicts rule to govern the rights and liabilities of the litigants in a diversity suit with multi-state factual contacts. ${ }^{15}$ But since the Supreme Court had not discussed the question in the Erie case, and then expressly reserved it in a subsequent decision, ${ }^{16}$ law review writers and federal courts readily joined debate on how the issue should be resolved. ${ }^{17}$

Many a cogent argument was advanced for the view that the matter should be handled as it had been theretofore. State conflict of laws rules were difficult to determine and nonexistant in many instances. ${ }^{18}$ By hypothesis, the cases in which the issue arose involved multi-state contactual facts and what state law should govern was more appropriately a matter for decision by the federal judge whose approach would be less apt to be tainted by the parochialism of state judges. If some

I4. Erie R. R. v. Tompkins, 304 U. S. 64 at 7I (1938). .

I5. Authorities are collected in McCormick and Hewins, note 7 supra, at 138 , n. 45 ; Note (I94I) 4I CoL. L. REV. I403, n. 3.

I6. Ruhlin v. New York Life Ins. Co., 304 U. S. 202, 208, n. 2 (1938). In Sibbach v. Wilson \& Co., Inc., 3I2 U. S. I (I94I), suit was brought in a federal district court of Illinois for bodily injuries inflicted in Indiana. The Federal Rules of Civil Procedure and the courts of Indiana provided for physical examination of the plaintiff upon order of the court, but Illinois did not authorize such a procedure. Justice Roberts stated that if the right to be exempt from the order of the court for physical examination is substantive, the district court would be required to apply the law of Indiana where the cause of action arose and to order a physical examination.

I7. For the view that the matter was one for the independent determination of the federal courts: Stentor Electric Mfg. Co., Inc. v. Klaxon Co., Ix5 F. (2d) 268, 275-277 (C. C. A. 3d, 1940) ; Note (1939) 52 HARv. L. REv. I002, I007; Griffin v. McCoach, II6 F. (2d) $26 \mathrm{I}$ (C. C. A. 5th, 1940) semble. Contra: Sampson v. Channell, IIo F. (2d) 754 (C. C. A. Ist 1940), (I940) 27 VA. L. REv. I20; a later decision by the Third Circuit itself in Waggaman v. General Finance Co. of Philadelphia, Pa., Inc., II6 F. (2d) 245, 257 (1940); Go0DRICH, CoNFLICT OF LAwS (2d ed. I938) \& I2; McCormick and Hewins, note 7 supra, at I38, 139. Cf. Cheatham, Sources of Rules for Conflict of Laws (194r). 89 U. OF PA. L. Rev. 430, 446, 447.

I8. See Goodrich, Mr. Tompkins Restates the Law (I94I) 27 A. B. A. J. 547, 548, where a quantitative analysis is made, state by state, of the instances where there is an absence of state decisions on propositions stated in the RESTATEMENT, CONFLICT OF LAws (I934). The maximum was 73\%, Tennessee; the minimum, 20.I\%, New York. 
of the facts transpired outside the United States, then certainly the federal judge should be free, in deciding the rule of reference, to consider the interests of the United States as a nation, rather than be bound by the limited views of a state judge. Finally, the old view would help promote a uniform conflict of laws.system in the United States, with the Supreme Court the ultimate arbiter as to choice of law rules. ${ }^{19}$

The opposition had for its case the clear cut policy position taken by the Supreme Court in Erie R.R. v. Tompkins that the accident of diversity of citizenship should not make possible a difference in the outcome of a lawsuit. If state $A$ says, in the case where a negligent act done in state $B$ starts a force which kills a.man in state $C$, suit for damages for death must be brought under the statute of state $B$; and the federal court in state $A$ points to the statute in state $C$, then a suit brought in the federal court may well arrive at a result different from that which would have been reached had suit been instituted in the state court "a block away." If this were permissible, "then the ghost of Swift v. Tyson" would indeed still walk "abroad, somewhat shrunken in size, yet capable of much mischief." 20 Furthermore, state conflict of laws rules are a part of state substantive common law ${ }^{21}$ and as such would appear to fall within the orbit of the Erie case.

The issue was finally resolved by the Supreme Court in Klaxon Co. v. Stentor Electric Mfg. Co., Inc. ${ }^{22}$ A judgment had been recovered in the federal court in Delaware for the breach of a contract made and to be performed in New York. The plaintiff then asked the court to correct the judgment by adding interest from the date the action had been commenced, in accordance with a provision of the New York Civil Practice Act. The Circuit Court of Appeals for the Third Circuit, relying on its independent determination of the conflict of laws rule to be applied, sustained the plaintiff's contention. ${ }^{22 a}$

On appeal, the Supreme Court disapproved of the lower court's disregard of the state choice of law rule as not in conformity with the principles of Erie R. R.v. Tompkins. It held that the conflict of laws

I9. For an excellent presentation of this side of the case see Cook, The Federal Courts and the Conflict of Laws (1942) 36 ILL. L. REv. 493, where the argument for the contrary view based on the assertion in the Erie decision that the course followed in Swift v. Tyson was unconstitutional is carefully appraised.

20. Judge Magruder in Sampson v. Channell, Iro F. (2d) 754, 76I (C. C. A. Ist, I940). Cf. the following quotation from Cook, note I9 supra, at 499, "The abolition of federal departure from state laws dealing with matters of wholly local concern which the Tompkins case has brought about seems to the present writer wholly desirable. It is another matter to extend state rules to conflict of law cases, which are not matters of wholly local concern to the various States, since they involve factual situations wholly or partially connected with other States or some foreign country."

2I. Restatement, Conflict of Laws (I934) \&5; Goodrich, Conflict of Laws (2d ed. I938) \$6.

22. 3 I 3 U. S. 487 (I94I).

22a. II5 F. (2d) 268 (C. C. A. 3d, I940). 
rule to be applied in a diversity of citizenship suit must conform to that prevailing in the courts of the state wherein the district court sits. "Otherwise," the court said, "the accident of diversity of citizenship would constantly disturb equal administration of justice in coordinate state and federal courts sitting side by side." 23

The decision of the Court in the Klaxon case was squarely rested upon the major premise of Erie R.R. v. Tompkins. The desirability of federal uniformity and policy was outweighed by the consideration that federal courts should not afford an opportunity to escape the judgment which would prevail in a state court.

Must a federal court in a diversity of citizenship case, however, invariably apply the conflict of laws rule which prevails in the state? There is at least one set of limitations which, though not giving a federal court freedom to formulate conflict rules of its own choosing, does permit it to reject the existing state choice of law rule. The limitations spring from the due process, full faith and credit, and perhaps other provisions of the federal Constitution. They have been invoked by the Supreme Court when state courts have made gross errors in choice of law problems, ${ }^{24}$ generally applying the law of the forum when the rule of reference required choice of the law of another state where the transaction took place. When an attack on a state conflict of laws rule predicated on these grounds will be successful in the federal forum is for the most part a matter of conjecture. ${ }^{25}$ In any event, a state rule will not be any more vulnerable when attacked in the federal court than it is when attacked in the state court. This has been made clear by the decision of the Supreme Court in Griffin v. McCoach, ${ }^{26}$ decided on the same day as the Klaxon case.

In the Griffin case, suit was instituted in a federal district court in Texas by the estate of a decedent, who had been a citizen and resident of Texas, for the proceeds of a life insurance policy. The insurance company successfully interpleaded the trustee of creditors who were the beneficiaries and the assignees of some of the creditors and paid the

23. $3 \mathrm{I} 3$ U. S. at 496.

24. E. g., Home Insurance Co. v. Dick, 28r U. S. 397 (I930) (due process); Bradford Electric Light Co., Inc. v. Clapper, 286 U. S. I45 (I932) (full faith and credit); Hartford Accident \& Indemnity Co. v. Delta \& Pine Land Co., 292 U. S. I43 (1934) (due process). See Western Union Telegraph Co. v. Brown, 234 U. S. 542 (I914) (commerce powers).

25. GoODRICH, CONFLICT of LAws (2d ed. I938) § II; Cheatham, note I7 supra, at 437-439; Dodd. The Power of the Supreme Court to Review State Decisions in the Field of Conflict of Laws (I926) 39 Harv. L. REv. 533; Hilpert and Cooley, The Federal Constitution and the Choice of Law (1939) 25 WASH. L. REv. 27; Overton, State Decisions in Conflict of Lazes and Review by the Supreme Court under the DueProcess Clause (1943) 22 ORE. L. REv. I09; Ross, Has the Conflict of Lazes Become a Branch of Constitutional Law? (193I) I5 MINN. L. Rev. I6I ; Smith, The Constitur tion and the Conflict of Lazes (1939) 27 GEo. L. J. 536.

26. 3 I3 U. S. 498 (I94I). 
proceeds into court. The assignees claimed they were entitled to the proceeds even though they had no insurable interests. The significant operative facts had transpired outside of Texas. Under the applicable foreign law the assignees were not required to have an insurable interest in the life of the insured and were entitled to the proceeds. But, it was the policy of Texas not to permit assignees to recover in Texas under such circumstances. The Supreme Court required the federal court to adhere to this policy of Texas. Since Texas could, under the Constitution, shut out the assignees under these circumstances and would have done so had suit been brought in its courts, a federal court sitting in Texas must do likewise. ${ }^{27}$

The facts of the Griffin case afforded a legitimate opportunity for deviation from the rule of the Klaxon case. Thus, according to Professor Cook, ${ }^{28}$ Texas can only determine public policy for its courts and not for federal tribunals; this was not an instance where a litigant resorted to a federal forum to gain an advantage over state law since the assignees were summoned into the Texas federal courts and had no election as to forum; under the Court's decision, a party who had never paid premiums might receive the proceeds ; ${ }^{29}$ and finally, most of the significant operative facts had occurred outside of Texas.

That a state forum in a conflict of laws case may, subject to constitutional limitations, refuse to recognize a cause of action founded upon a foreign. set of operative facts is an accepted infirmity of the prevailing conflict of laws system. But, to perpetuate this infirmity in the federal courts, where jurisdiction for suits between citizens of different states was created to afford an impartial tribunal free from local prejudices, ${ }^{30}$ vitiates that very purpose of diversity of citizenship

27. For comments on the Klaxon and Griffin decisions see: Cook, note Ig supra; Notes (I94I) Col. L. Rev. I403 and 8 U. of PITt. L. Rev. 60; (I94I) I5 S. CalIf. L. REv. 95; (1942) 6 MD. L. REv. I60; (I94I) 40 MiCH. L. Rev. I26; (1942) 20 TEX. L. REv. 375 .

28. Cook, note I9 supra.

29. See decision of Circuit Court of Appeals on remand, I23 F. (2d) 550 (C. C. A. 5th, I94I), cert. denied, 316 U. S. 683 (I942).

30. It may be argued that the local hostility and discrimination which diversity of citizenship jurisdiction was intended to obviate was that which would manifest itself only on a personal level in the court room. The local jurors would, in reaching their verdict, reflect their animosity towards "foreigners." Perhaps the county judge would for similar reasons not be an impartial dispenser of 'justice. But, diversity of citizenship jurisdiction would hardly surmount local prejudice as it manifests itself at these levels since federal judges and federal juries are selected from the local populace. On the other hand, discrimination cloaked in the form of a state statute or a state judicial opinion which requires a court to disregard the law indicated by the usual rules of reference could be overcome in the federal court if the federal court were not bound by the state law. Granted that in the Griffin case local prejudice was directed not against a person as such but against rights established under the law of another state and that Texas would apply the same rule if such rights were acquired by a Texas citizen as well as a non-citizen, nevertheless, a federal court, if it is to achieve one of the main objectives of diversity of citizenship jurisdiction, should be free to disregard local disregard of rights acquired without the state. 
jurisdiction. Of course, if the district court in Texas were free to disregard Texas policy, the result in the federal court would have been different than the result which would have been reached if suit had been instituted in the state court "a block away." To that extent there would not have been uniformity in the coordinate administration of state law in federal and state courts sitting side by side. But diversity of citizenship jurisdiction is not a mere accident insofar as suits in the federal courts are concerned where the matter at stake is local discrimination. The desirable goal of obtaining uniformity could justifiably have been yielded in the Griffin case to the consideration of freedom from local discrimination which the federal courts are supposed to assure.

The refusal of the Supreme Court to yield that goal leaves a federal judge free to disregard an established state rule of reference only when it violates the federal Constitution. Even then, however, the federal judge will have to determine what the state rule would be were the state court confronted with such a ruling by the Supreme Court of the United States.

\section{II}

"The line between procedural and substantive law is hazy but no one doubts federal power over procedure." 31

For some sixty years prior to Erie R. R. v. Tompkins federal "practice, pleadings, and forms and modes of proceedings in other than equity and admiralty causes" had to conform "as near as may be" to practice in like causes in state courts wherein the federal courts sat. ${ }^{32}$ Matters pertaining to procedure, not caught up by the Conformity Act, but embraced by a state statute were controlled by the state statute under the Rules of Decision Act. ${ }^{33}$

In some instances, however, federal courts were free not to follow state law when dealing with matters generally characterized as procedural. This was the case when application of the Conformity Act would have interfered with and affected the common law functions of the trial judge. Excepted this way were such matters as the manner of instructing a jury, expressions of opinion upon the evidence, and the conditions under which a judge should or should not direct a verdict where the evidence presented was such that a verdict the other way would have been set aside. ${ }^{34}$ "This discharge of the judicial function

3r. Justice Reed, concurring in Erie R. R. v. Tompkins, 304 U. S. at 92.

32. The Conformity Act, I7 STAT. I97, \$ 5, 28 U. S. C. (I934 ed.) \$724 (1934). (1945).

33. See Guaranty Trust Co. of New York v. York, 326 U. S. 99, IIO, III.

34. See Herron v. Southern Pacific Co., 283 U. S. 9 I (I93I) ; I MOoRE AND FRIEDman, Moore's Federat Practice (I938) § 0.03 . 
as at common law" was declared to be "an essential factor in the process for which the Federal Constitution provides." 35 Matters governed by the federal Constitution, such as the right to a jury trial by twelve, were also ones for independent federal determination. Finally, the federal courts characterized as substantive some matters generally characterized as procedural, such as burden of proof, ${ }^{36}$ and freed themselves from the bonds of state practice in those instances also.

In the same year in which the Supreme Court decided that federal courts must, in diversity of citizenship cases, look to state law to determine the substantive rights of litigants, an equally radical change took place in federal procedure. The Federal Rules of Civil Procedure, authorized by the Enabling Act of $1934,{ }^{37}$ freed federal courts from following state procedure and practice. ${ }^{38}$ A system of federal rules of procedure was permissible under the opinion in the Erie case since it was construed not to infringe upon federal power to regulate procedural matters in the federal courts. However, both the Federal Rules and the Erie case excepted from federal power matters dealing with "substantive" rights. The Federal Rules would be bad to the extent they exceeded this limitation.

Many matters, generally characterized as procedural, did not come within the scope of a set of rules to govern court procedure and were either not covered or just glossed over by the rules. These included, among other things, judicial notice of the law of another state, ${ }^{39}$ burden of proof, ${ }^{40}$ statutes of limitations, ${ }^{41}$ and perhaps statutes of fraud ${ }^{42}$ and measure of damages. ${ }^{43}$ If federal courts could characterize as procedural that which had generally been so characterized in the conflict of laws, a wide area of freedom from state law would still remain. But, was such a position tenable in light of Erie $R$. R. v. Tompkins?

The basic issue presented in view of the Erie decision was whether it is more desirable for the federal judiciary to have uniform rules gov(I93I).

35. Chief Justice Hughes in Herron v. Southern Pacific Co., 283 U. S. at 95

36: Goodrich, Conflict of Laws (2d ed. I938) p. I99, n. 46.

37. "The Supreme Court of the United States shall have the power to prescribe, by general rules, for the district courts of the United States and for the courts of the District of Columbia, the forms of process, writs, pleadings, and motions, and the practice and procedure in civil actions at law. Said rules shall neither abridge, enlarge, nor modify the substantive rights of any litigant. . . all laws in conflict therewith shall be of no further force or effect." 48 STAT. ro64, 28 U. S. C. $\$ 723$ (b) (1940).

38. Doubt has been voiced as to whether the Conformity Act has actually been repealed by the Enabling Act of 1934: "Status of the Conformity Act," 2 FED. RuLES SERv. (I940) p. 625; Tunks, Categorization and Federalism: "Substance" and "Procedure" After Erie Railroad v. Tompkins (1939) 34 ILL. L. REv. 27I, 288-29I. But see Sibbach v. Wilson \& Co., Inc., 3I2 U. S. I (I94I).

39. Strahorn, The Process of Judicial Notice (I928) I4 VA. L. REv. 544, 563.

40. GOODRICE, CoNflict of Laws (2d ed. 1938) \$8I.

4I. Id. at $\$ 82$.

42. Id. at $\$ 85$.

43. Id. at $\$ 88$. 
erning the manner in which litigation is to be conducted in its courts than to assure litigants that their rights and liabilities will not be materially affected by virtue of suit being brought in the federal courts. The Federal Rules of Civil Procedure, expressing the policy of the Congress and, to some extent, the views of the Supreme Court itself, supported the first of these choices. Erie R. R. v. Tompkins indicated the latter. Proponents of either choice readily compromised this apparent conflict to their individual satisfaction by varying the dimensions of the hazy in-between which fuses "substance" with "procedure." 44

Judge Clark early rejected the test with respect to the Federal Rules of Civil Procedure that if a rule affected substantial rights or was an important factor in the outcome of a case it must be set aside and the state rule followed. The policy expressed in Erie R. R. $v$. Tompkins could be reconciled with a uniform system of federal procedural rules if the federal court would not hold that an issue, traditionally procedural or on the borderline, is substantive unless the public policy of the state, as unequivocally disclosed by some clear state statute or decision, demanded such a result. ${ }^{45}$

The view that uniformity of result in the federal and state courts should be largely determinative of whether state law controls has been championed by Professor Morgan in a recent law review article discussing matters of proof." administration of justice in our federal system to prevent a party from taking advantage of the accident of diversity of citizenship to secure the benefits of a more favorable rule of law than to prevent him from taking a like advantage of his own immunity from service of process or his opponent's liability to such service because of the accident of locality."

The general problem may be divided into two parts, one embracing those matters expressly provided for in the Federal Rules of Civil Procedure and the other including those matters not so covered. With respect to the former, a number of rules have been the subject of wide-

44. See Cook, "Substance" and "Procedure" in the Conflict of Laws (I933) 42 YaLE L. J. 333.

45. Clark, Procedural Aspects of the New State Independence (I940) 8 Gro. WAsH. L. REv. I230; Clark, The Tompkins Case and the Federal Rules (I94I) 24 J. AMr. Jud. Soc. I58. In the latter article Judge Clark urges that it should be presumed that the Federal Rules of Civil Procedure are "procedural" and that a federal judge should not go beyond a state judge in deciding what is substantive. $C f$. (I939) $87 \mathrm{U}$. of PA. L. REv. 344, 345, where it is suggested that the determination in the first instance of whether burden of proof on the issue of contributory negligence is "procedural" or "substantive" is in itself "substantive" "because a decision on an issue of whether a given law does or does not 'relate to the rights and duties which give rise to a cause of action' must itself relate to those rights and duties."

46. Morgan, Choice of Law Governing Proof (I944) 58 HARv. L. Rev. I53, r89. 
spread discussion and many decisions, with opinion often divided as to their validity. ${ }^{47}$

In Sibbach v. Wilson \& Co., Inc., ${ }^{48}$ the Supreme Court had occasion to consider the validity of rule 35 providing for the physical and mental examination of persons: It was conceded that the rule dealt with procedure but it was argued that "substantive rights" as used in the Enabling Act were not limited to matters of substance, in the general sense of the word, but also included "important and substantial rights." Justice Roberts, speaking for the majority of the Court, found the rule within the mandate of Congress. Although there was no question presented of "substance" versus "procedure" and federal power versus state power, the case is of interest in two major respects. The majority opinion attached significance to the fact that in the final hearing on the rules by the Congress, objections of the kind raised in the case were made and Congress did not disapprove the rule. "Evidently the Congress felt the rule was within the ambit of the statute. . . " 49 The other point of interest is the test for "procedure" which Justice Roberts hazarded: "The test must be whether a rule really regulates procedure-the judicial process for enforcing rights and duties recognized by substantive law and for justly administering remedy and redress for disregard or infraction of them." ${ }^{50}$

Several years later, the Court, in considering the validity of rule 4 (f) authorizing state-wide service of process, enlarged upon both of these points: The fact that the Supreme Court had promulgated the Federal Rules of Civil Procedure did not foreclose consideration of their validity, meaning or consistency. But, the meaning attributed to the rules by the Advisory Committee was entitled to weight and opinions

47. E. g., "Commencement of Actions and the Statute of Limitations" (I94I) 4 Fen. Rures Serv. 884 (Rule 3); Williams v. James, 34 F. Supp. 6I, 68, 69 (W. D. La., I940) (Rule 4 (f) service of process throughout state); note 5 I infra (Rule 8 (c) burden of proof on the issue of contributory negligence); John R. Alley \& Co., Inc. v. Federal Nat. Bank of Shawnee, Shawnee County, Okla., 124 F. (2d) 995 (C. C. A. Ioth, I942) (Rule 13, cross-claim or counter-claim) ; Brown v. Cranston, I32 F. (2d) 63I, cert. den. sub nom. Cranston v. Thompson, 319 U. S. $74 \mathrm{I}$ (I943) (Rule 14, third party practice) ; Pitcairn v. Rumsey, 32 F. Supp. I46, I49, I50 (W. D. Mich., 1940) and Allegheny County, Pa. v. Maryland Casualty Co., 32 F. Supp. 297 (W. D. Pa., 1940) (Rule I8 (b), joinder of remedies); Doyle v. Stanolind Oil \& Gas Co., I23 F. (2d) 900, 903 (C. C. A. 5th, I94I) (Rule 20 (a), joinder of parties); "Substance and Procedure in Stockholders' Suits: Ozmership of Stock at Time of Acts Complained of" (I94I) 4 FED. RuLES SERv. 909 (Rule 23 (b)); Holtzoff, Equitable and Legal Rights and Remedies under the New Federal Procedure (I943) 3 I CALIF. L. REv. I27, I37-I40, and Morris, Jury Trial under the Federal Fusion of Law and Equity (I942) 20 TEx. L. REv. 427 (Rule 38, jury trial); "The 'Two Dismissal' Rule" (I94I) 4 FED. Rules SERV. 927 (Rule $4 \mathrm{I}(\mathrm{a})$ ).

See generally, Ilsen, Recent Cases and New Developments in Federal Practice and Procedure (194I) I6 ST. JoHN's L. REv. I, 28-44; Clark, note 45 supra; Tunks, loc. cit. supra note 38 .

48. 312 U. S. I (I941).

49. 312 U. S. at 15.

50. 3I2 U. S. at I4. 
of authorized spokesmen of the Committee that rule 4 (f) related to procedure were of important significance. Most alterations of rules of practice and procedure often do affect the rights of litigants but the prohibition of the Enabling Act was not addressed to incidental effects, which necessarily attend the adoption of the prescribed new rules, upon litigants properly before a court. Rule 4 (f) did not abridge, enlarge or modify the rules of decision by which a court adjudicates a litigant's rights but merely related to the manner and means by which a right to recover is enforced and was, therefore, a rule of procedure and not of substantive right. ${ }^{\text {.0a }}$

Of all the rules, rule 8 (c) aroused the most widespread concern and comment. ${ }^{51}$ It requires the defendant to plead affirmative defenses, including that of contributory negligence. Was this rule bad in cases where the state law placed the burden of pleading on the plaintiff? Did rule 8 (c) control the burden of proof also and, if so, was the state rule of burden of proof nevertheless the one to be followed? The burden of pleading is expressly provided for in rule 8 (c); the burden of proof is not.

Palmer v. Hoffman ${ }^{52}$ resolved both these questions. Suit was brought in a district court of New York for negligent injury resulting from a grade crossing accident in Massachusetts. Two of the causes of action rested upon a Massachusetts statute creating a new right. The Massachusetts statute placed the burden of proving contributory negligence on the defendant. Two of the causes of action were founded on the common law. The trial judge, without distinguishing among the causes of action, charged that the burden of proving contributory negligence was on the defendant.

The Supreme Court held that rule 8 (c) covered only the manner of pleading contributory negligence and did not purport to dispose of who had the burden of proof on this issue. Pleading, it held, was appropriately governed by rule 8 (c).

Then, relying on its decision in Cities Service Oil Co. v. Dunlap ${ }^{53}$ and, to some extent, on the traditional federal view as to burden of

50a. Mississippi Pub. Corporation v. Murphree, 66 S. Ct. 242, 246 (1946).

5I. For a collection of early decisions, see Clark, note 45 supra, 24 J. Arr. Jud. Soc. at 159 n. 7. Sampson v. Channell, IIo F. (2d) 754 (C. C. A. Ist, I940) to the effect that the federal court must follow the rule of the state in which it sat, whether regarded as substantive or procedural by the state, was the leading lower court decision. See Comments (1940) 20 B. U. L. Rev. 566, 53 HARv. L. REv. 1393, (I94I) 29 CaltF. L. Rev. 228.

52. 318 U. S. 109 (1943).

53. 308 U. S. 208 (I939). In the Dunlap case, suit was brought to remove a cloud from title to an oil and gas lease in Texas. The respondents, in a cross-bill, asserted that the complainant's chain of title was defective in description of boundaries. The latter denied the allegations of the cross-bill and asserted that it and its predecessors had purchased for value and in good faith and without notice of mistake. The complainant claimed that under Texas law the burden of proof on the issue of 
proof, the Court flatly asserted that burden of proof on the issue of contributory negligence was a question of local law which federal courts in diversity of citizenship cases must apply. It upheld the charge of the trial judge insofar as it pertained to the statutory causes of action since the New York conflict of laws rule in such a case required that burden of proof on the issue of contributory negligence be determined by reference to the statute of the state creating the cause of action. The Massachusetts statute required the defendant to establish contributory negligence, and the finding of the lower court that New York would apply the Massachusetts rule was not disturbed by the Supreme Court, since a federal district court sitting in New York was bound to apply the New York conflicts rule.

With respect to the common law causes of action, the lower court had made no distinction between the conflict of laws rule applicable to them and the conflict of laws rule governing the statutory causes of action. But, the Supreme Court cited New York decisions which intimated that in the common law actions New York regarded the matter as procedural and applied the rule of the forum which placed the burden on the plaintiff. Because the defendant had merely offered a general exception to the charge of the trial judge, however, the Supreme Court did not reverse the judgment and remand the case for a determination of the appropriate New York rule. But, the Court left little doubt that, if the point had been properly reserved and it had been determined that New York would have applied its own internal rule as to burden of proof, the federal court could not have applied any other rule.

Under the Palmer case, therefore, a federal court in a diversity of citizenship case must place the burden of proof on the issue of contributory negligence upon that party to the law suit upon whom the state, in which the court sits, would place the burden had suit been brought there. Conventional conflict of laws characterization of burden of proof as "procedural" is inapplicable and it makes no difference, insofar as the independence of the federal court from state law is concerned, whether the state court regards the matter as "procedural" or "substantive."

bona fide purchaser for value and without notice was upon him who attacks the legal title and asserts a superior equity, in this case, the respondents and insisted Erie $R$. $R$. v. Tompkins required adherence to this rule. The Circuit Court of Appeals pointed out that the state view was as claimed by the complainant and differed from the views of other jurisdictions. But, it held that this was merely a question of proper practice in courts of equity and Erie $R . R . v$. Tompkins was not applicable. The Supreme Court reversed the decision of the lower court and held that proof the complainant did not purchase for value and in good faith was part of the very substance of the cause of the respondents and that it was a "substantial right" upon which the holder of legal title to Texas land may confidently rely. (Rule 8 (c) was not involved in the Dumlap 
Stoner v. New York Life Ins. Co. ${ }^{54}$ also was concerned with the matter of proof in the federal courts. After a state appellate court had twice held that evidence on total disability was sufficient to send the case to the jury, the federal Circuit Court of Appeals in a declaratory judgment action between the same parties reversed a finding by the trial judge, sitting without a jury, that the evidence presented established total disability. The Supreme Court reversed the Circuit Court of Appeals. The test for determining total disability had been defined by the state court and it had been held, on almost the same evidence, that the question was one for the jury. The federal court could not hold otherwise.

The Stoner case appears to be an inroad upon the federal view before Erie R. R. v. Tompkins that, in the exercise of common law functions of a trial judge, the federal judge is not bound by state law. Under the Stoner decision a federal judge is bound by state law, even in the exercise of these functions, where it is clear that freedom from a state's views would cause an important difference in the outcome of the litigation. However, unlike other instances involving the applicability of state law, it probably will not be clear that the result in the federal litigation will be different unless a lawsuit between the same parties over the same issues in the state court can be relied upon, as it was in the Stoner case. Unless this can be established, a federal judge should not be bound by state law in such matters as commenting upon the evidence or the credibility of witnesses, and the granting of a new trial if the verdict appears to the judge to be against the weight of the evidence..$^{55}$

The applicability of state statutes of limitations to diversity of citizenship actions in the federal courts, a problem not covered by the Federal Rules of Civil Procedure, presented another instance for delimitation of federal and state spheres of controlling law. In actions formerly cognizable at law, local statutes of limitation were applicable under the Rules of Decision Act. Serious doubt existed as to the circumstances under which they were applicable in the federal equity court. ${ }^{56}$

The principles of Erie R.R. v. Tompkins, it had been settled, were equally valid in diversity actions in the federal courts formerly cognizable in equity. ${ }^{57}$ This was defined to mean that although the substantive rights and obligations of parties were governed by state law, the form of equitable relief was to be determined by the federal courts

54. 3rI U. S. 464 (1940).

55. Cf. Morgan, note 46 supra, at 176 .

56. Cf. Russell v. Todd, 309 U. S. 280 (1940).

57. Ruhlin v. New York Life Ins. Co., 304 U. S. 202 (1938) ; Cities Service Oil Co. v. Dunlap, 308 U. S. 208 (1939). 
independent of state law. ${ }^{58}$ There was some basis, therefore, for a rational argument that state statutes of limitations went to the remedy and were, therefore, inapplicable in federal equity actions.

A majority of the Second Circuit thought they were inapplicable. ${ }^{59}$ A majority of the Third Circuit, relying on niceties previously enunciated by the Supreme Court, thought that they must be applied.60 On certiorari to the Second Circuit in its case, York v. Guaranty Trust Co. of New York, the Supreme Court held that the state statute of limitations governed. ${ }^{61}$

Conventional conflict of laws distinctions between "substance" and "procedure" were again brushed aside. It was indicated that if this terminology is to have any use in the federal forum in a diversity of citizenship case it must denote something different than when it is used in a state forum conflict of laws situation. In the federal forum "The question is whether such a statute (of limitations) concerns merely the manner and the means by which a right to recover, as recognized by the State, is enforced, or whether such a statutory limitation is a matter of substance in the aspect that alone is relevant to our problem, namely, does it significantly affect the result of a litigation for a federal court to disregard a law of a State that would be controlling in an action upon the same claim by the same parties in a State court?" 62 If the matter intimately affects recovery or non-recovery, a federal court in a diversity case must follow state law; otherwise the intendment of Erie R. R. v. Tompkins would be defeated. ${ }^{63}$

The pattern woven by the Palmer, Stoner, and York decisions appears clear at this date. Conventional conflict of laws characterization of matters as "procedural" or "substantive" has little if any bearing upon whether a federal court in a diversity suit is or is not to apply state law in cases where there is no applicable Federal Rule of Civil Procedure. In such instances it is more important and desirable for federal courts to achieve uniformity with state administration of state law. This objective cannot be achieved if the federal court is free to make determinations independent of state law and such freedom will, almost as a matter of law, yield a result substantially different from that which would have obtained in the state court where the federal court sits. The critical test in such instances, therefore, is whether an important

58. Black \& Yates, Inc. v. Mahogany Ass'n, Inc., r29 F. (2d) 227 (C. C. A. 3d, I942); Maxwell v. Enterprise Wall Paper Mfg. Co., I3I F. (2d) 400 (C. C. A. 3d, 1942).

59. York v. Guaranty Trust Co. of New York, I43 F. (2d) 503 (I944).

60. Overfield v. Pennroad Corp., I46 F. (2d) 889 (I944).

6I. Guaranty Trust Co. v. York, 326 U. S. 99 (I945).

62. Id. at $\log$ (I945).

63. For a subsequent comment by the Court on the York, decision, see Holmberg v. Armbrecht, $66 \mathrm{~S}$. Ct. 582, 583, 584 (1946). 
difference in result will be made possible if state law is not applied. If it will be made possible, state law controls. Thus, for example, state statutes of frauds, some state rules of judicial notice, and state rules as to measure of damages should be controlling in diversity actions in the federal court. ${ }^{\text {osa }}$

The same principles should be applicable in those matters which have been referred to as concerning the exercise of judicial functions by the trial judge as at common law. This will still permit an area of freedom from state law since it will be very difficult to establish that comments or the lack of comments by a trial judge on the credibility of witnesses or on the weight of the evidence or the manner of instructing a jury will necessarily make a difference in the outcome of litigation.

The path is not as well defined in the case of the Federal Rules of Civil Procedure. Certainly the application of a number of the rules will, to the extent that state law is contrary, cause a different result in the federal court than would have been reached in the local state court. If the rules are to be upheld in the interests of a uniform system of federal procedure the above test is inadequate. In view of the admitted federal power over procedure in the federal courts, it is submitted that when the Congress has exercised that power, it has in a sense "occupied the field" and the test should be whether the rule has any relation as to how a federal court shall conduct its business. If it does, the rule should be upheld. Under this test, for example, the federal rule that a plaintiff in a class action must allege that he was a shareholder at the time of the transaction complained of will be valid because it expresses a policy that a federal court shall not open its doors to anyone who has purchased his way into a lawsuit. There is some foundation in the Sibbach, Murphree and Palmer decisions for such a test.

III

". . . the law of the state . . . declared by its Legislature in a statute or by its highest court in a decision. . . ." 64

After the Tompkins case, it was clear that the federal judge would have to pay due deference to state law as declared by the highest court of the state. Accommodation to this restriction of his freedom, though unpleasant, might be bearable. But surely, if the state's highest court

63a. A per curiam opinion in American Seating Co. v. Zell, 322 U. S. 709 (I944), stated that four members of the Court were of the opinion that proof of a contract alleged in affidavits on a motion for summary judgment was precluded by the applicable state parol evidence rule. The Court has reserved decision on the questions whether a federal court in a diversity case is required by the Tompkins decision to apply state rules of forum non conveniens, Williams v. Green Bay \& W. R. R., 66 S. Ct. 284 (1946), res judicata, Heiser v. Woodruff, - U. S. - (I946), a non-diversity action.

64. Justice Brandeis in the Erie case, 304 U. S. 64,78 (1938). 
had not ruled upon the point in issue, the federal judge would be able to exercise his learning in the law? This illusion, though plausible under the language in which the Tompkins decision was cast, was thoroughly shattered by three opinions handed down by the Supreme Court on December 9, I940.

In Fidelity Union Trust Co. v. Field ${ }^{65}$ the validity of a New Jersey testamentary trust was in issue. A state statute dealing with the matter had already been twice construed by the Chancery Court of New Jersey, a court of first instance with state wide jurisdiction in equity suits. The statute had not been construed, however, by the lower law courts, or by the Court of Errors and Appeals, the highest court of the state. The Circuit Court of Appeals for the Third Circuit thought that the construction of the statute by the Chancery Court was wrong and rejected it. ${ }^{68}$ The United States Supreme Court reversed: "An intermediate state court in declaring and applying the state law is acting as an organ of the State and its determination, in the absence of more convincing evidence of what the state law is, should be followed by a federal court in deciding a state question ... whether the question is one of statute or common law." ${ }^{77}$ The evidence relied upon by the Circuit Court of Appeals, the statute itself, did not establish that the law of the state was other than as stated by the Chancery Court.

The same view was expressed in another of the cases where the decision of the state court was that of an intermediate court of less than state wide appellate jurisdiction, there being no convincing evidence that the law of the state was to the contrary. ${ }^{68}$

In West v. American Telephone and Telegraph Company ${ }^{69}$ one phase of the very matter before the federal court had been litigated by the same parties in a lower state court. The federal court was required to apply the state law as found in that litigation. ${ }^{70}$

Narrowly construed and literally applied, these decisions would bind federal judges, hand and foot-and mind, to the legal mentalities of judges of any court of a state. A litigant in the federal court would be submitting his "fortunes to the decision of a court that can read but must not reason."71 A possible escape, however, from such complete confinement, lies in the opinion of Chief Justice Stone in the West case where he pointed out that it is the duty of a federal court to ascer-

65. 3II U. S. I69 (I940).

66. $108 \mathrm{~F}$. (2d) $52 \mathrm{I}$ (1939).

67. 3 II U. S. at I77.

68. Six Companies of California v. Joint Highway District No. I3 of California, 3 II U. S. I80 (r940).

69. 3II U. S. 223 (1940).

70. See also Stoner v. New York Life Ins. Co., 3Ir U. S. 464 (1940).

7I. Corbin, The Laws of the Several States (I94I) 50 YALE L. J. 762, 768, discussing the above three cases. 
tain state law from "all the available data" and not to depart from what a lower state court announces as law unless "it is convinced by other persuasive data that the highest court of the state would decide otherwise." 72

What are such "data"? A fortiori, a decision of the highest court of a state is a conclusive datum unless subsequently overruled by that court. And if a state decision is overruled while the case in the federal court is sub judice, the latest expression of state law is controlling. ${ }^{73}$ Well considered dicta of the highest court of a state will be of great weight; less weighty will be the dicta of lower courts. It has also been suggested that a court's own doubts as to its decision, ${ }^{74}$ analogies in the decisions of the highest court of a state, the views of specialty courts and legislative material ${ }^{\mathbf{7 5}}$ may serve to outweigh the decision of an inferior state tribunal. Refusal of the highest court of a state to review an intermediate state court decision, on the other hand, is an important indication that the latter represents the law of the state. ${ }^{76}$ Another guide of particular value where there is not even a lower state court decision in point and already tried with success by the Third Circuit, will be the book sources of law of state courts. ${ }^{77}$ Resort to all available devices will have to be had if decisions in litigation in the federal courts are to be arrived at in accordance with the principles of the Erie case.

72. 3II U. S. at 237.

73. Vandenbark v. Owens-Illinois Glass Co., 3II U. S. 538 (I94I), where a state decision was overruled while an appeal from the decision of the federal trial court was pending in the Circuit Court of Appeals.

In Huddleston v. Dwyer, 322 U. S. 232 (I944), the Supreme Court clearly intimated that if the state court had changed its views while a case was pending before the United States Supreme Court, the latter would apply the latest state decisision itself. However, if the effect of the latest decision of the state court were not clear, the Supreme Court would remand the case, as it did in this instance, for the lower court to interpret and apply the state decision.

74. Note (I94I) 9 Geo. Wash. L. Rev. 458.

75. Note (I94I) WIS. L. REv. 528. The weightiness of legislative material such as, statutes, debates, and hearings, is highly questionable in view of the Field case. See Corbin, note 71 supra, at 774 .

76. See the opinion in the West case, 3II U. S. at 237.

77. Stentor Electric Mfg. Co. v. Klaxon Co., on remand, I25 F. (2đ) 820 (I942). Judge Goodrich examined what sources the Delaware court resorted to in a decision requiring the determination of a conflict of laws rule, in the absence of prior state decisions. The Delaware court had cited cases from other states, three current text books on the confict of laws and the RESTATEMENT OF THE LAW. The Delaware court it was found, accepted and applied what was set forth in those sources and the court felt that this was strong evidence of what the Delaware court would do in a conflict of laws problem. Of particular significance, in the view of the court was the fact that the RESTATEMENT OF THE LAW had been cited in sixty-eight instances in reported Delaware decisions and fourteen of these citations were to the volume on the conflict of laws. The court, therefore, concluded that the Delaware court would follow the view expressed in these authorities and so held. See also Goodrich, note 18 supra, and Proof of the Pudding (I94I) 27 A. B. A. J. 77I. 
Absence of specific and relevant state decisions is no excuse for the federal court refusing to decide a case and requiring the parties to litigate the issues in the state court. ${ }^{78}$ Even though the decision of a federal court will not finally settle the questions of state law involved, it must determine those questions as best it can with the aid of such light as is "afforded by the materials for decision at hand. . . ." 79 And such a determination of the law of a state made by a federal judge of that state and affirmed by the Circuit Court of Appeals, will not be disturbed by the Supreme Court. ${ }^{80}$

The indicated "materials for decision at hand" are no doubt but a segment of the data used by a state court in deciding a case. Whether, in view of the decisions by the Supreme Court, the data that may be resorted to will be limited to materials of such a nature or will also include, as has been suggested, ${ }^{81}$ the local social, political and economic guides relied upon by state courts remains to be seen. ${ }^{82}$ Certainly, a permissible latitude in this respect which is an inverse function of the extent to which the law of a state has been defined by its courts would not vitiate the doctrine of Erie R. R. v. Tompkins.

The decisions of the Supreme Court since Erie R. R. v. Tompkins have unfailingly applied the basic principle of the Erie case that the result in a diversity of citizenship suit must not differ substantially merely because suit is brought in the federal forum rather than the state court, except insofar as the result is controlled by the federal Constitution and federal statutes. Conventional conflict of laws standards have been cast aside in the quest of this objective.

Yet, the theory underlying Erie $R . R$. v. Tompkins and the decisions that have followed are not at variance with the ultimate objective of a conflict of laws system that the fortuitous choice of a forum shall

78. Meredith v. Winter Haven, 320 U. S. 228 (I943). Also impractical and circuitous are the suggestions advanced for legislation permitting a federal court to certify to the highest court of a state doubtful questions of state law (Note (I94I) 9 GEO. WASH. I. REV. 458, 465) and for amendment of the federal Judiciary Act to deny diversity of citizenship jurisdiction where state law is unsettled (Note (I94I) WIS. L. REV. 528, 532).

79. Meredith v. Winter Haven, 320 U. S. at 238.

80. MacGregor v. State Mutual Life Assurance Co., 3 I5 U. S. 280 (I942).

81. See Corbin, note 7I supra, at 774 .

82. Cf. Williams v. Green Bay \& W. R. R.,

U. S.

(1946). An action, brought by debenture holders of a Wisconsin railroad to recover amounts alleged to be due and payable under the debentures out of earnings in lieu of interest, was removed to a federal district court in New York. In seeking dismissal of the action, it was suggested by the defendant that the parties should be remitted to Wisconsin because a construction of the covenant in the debenture relied upon for the action would primarily affect the interests of the public in Wisconsin where the defendant's railroad lines were located. The Court rejected this contention pointing out that "such considerations will frequently be involved in applying the rule of Erie $R$. $R$. v. Tompkins, supra. They go no further than to suggest one additional phase of local law which the federal court, whether it sits in New York or in Wisconsin, may have to apply." 
not make any important difference in the final determination of the rights and obligations of litigants. The fact of the matter is that by virtue of the federal system this goal is being more readily attained as between the federal forum and the forum of the state in which the court is situated, than as between one state forum and the forum of another state. 